географії, засобом становлення професійної компетентності майбутнього вчителя географії.

\title{
Література
}

1. Ананьев Б. Г. Человек как предмет познания / Б. Г. Ананьев. - [3-е изд.]. СПб. : Питер, 2001. - 288 с. 2. Артюшина М. В. Взаємозв'язок соціальнопсихологічних та дидактичних умов групової навчальної діяльності студентів : автореф. дис. на здобуття наук. ступеня канд. пед. наук : спец. 13.00.04 «Теорія і методика професійної освіти»/ М. В. Артюшина. - К., 2000. - 20 с. 3. Ващенко Г. Загальні методи навчання : [підручник] / Г. Ващенко. - Х. : Держвидав України, 1929. - 232 с. 4. Герд В. А. Экскурсионное дело / В. А. Герд. - М. : Госиздат, 1928. 115 с. 5. Желудковский Е. А. Основы экскурсионного дела : [учеб. пособ.]/ Е. Желудковский, Е. Лукьянова. - Ялта : РИО КГУ, 2008. - 280 с. 6. Куразова Н. Ф. Методика преподавания географии / Н. Ф. Куразова. - М. : Просвещение, 1999. 258 с. 7. Педагогическая энциклопедия / ред. А. И. Каиров, Ф. Н. Петров. - М. : Сов. энцикл., 1964. - Т. 3. - 832 с. 8. Родіна О. П. Групові форми як один із шляхів стимулювання самостійності учнів / О. П. Родіна // Географія. - 2007 - № 8. - С. $17-$ 19.

УДК 378. 147

Олена Драшко

\section{СИСТЕМА ПЕДАГОГІЧНИХ УМОВ ПІДГОТОВКИ ВЧИТЕЛІВ ОБСЛУГОВУЮЧОЇ ПРАЦІ ДО ВИКОРИСТАННЯ ХУДОЖНІХ РЕМЕСЕЛ У НАВЧАЛЬНО-ВИХОВНОМУ ПРОЦЕСІ}

Драшко О. М. Система педагогічних умов підготовки вчителів обслуговуючої праці до використання художніх ремесел у навчально-виховному процесі.

У статті обгрунтувано систему педагогічних умов підготовки вчителів обслуговуючої праці до використання художніх ремесел. Розкрито критерії, показники та рівні підготовки фахівців; етапи впровадження системи обгрунтованих педагогічних умов у навчально-виховний процес ВНЗ 3 підготовки вчителів обслуговуючої праці до використання художніх ремесел у навчально-виховному процесі.

Ключові слова: освітньо-виховний потенціал художніх ремесел, освітньо-виховні функції художніх ремесел; пошуково-творчий, потенційно-можливий, задовільний, недостатній рівні підготовки вчителів обслуговуючої праці до використання художніх ремесел у навчально-виховному процесі.

Драшко Е. Н. Система педагогических условий подготовки учителей обслуживающего труда к использованию художественных ремесел в учебновоспитательном процессе.

В статье обоснована система педагогических условий подготовки учителей обслуживающего труда к использованию художественных ремесел. Раскрыты критерии, показатели и уровни подготовки специалистов, этапы внедрения системы обоснованных педагогических условий в учебно-воспитательный процесс вуза по подготовке учителей обслуживающего труда к использованию художественных ремесел в учебно-воспитательном процессе.

Ключевые слова: образовательно-воспитательный потенциал художественных ремесел; образовательно-воспитательные функции художественных ремесел; поисково-творческий, потенциально-возможный, удовлетворительный, 
недостаточный уровни подготовки учителей обслуживающего труда к использованию художественных ремесел в учебно-воспитательном процессе.

Drashko O. M. The system of pedagogical conditions in training maintenance personnel teachers to use artistic handicrafts in a teaching and educational process.

The article substantiates the system of pedagogical conditions in training maintenance personnel teachers to use artistic handicrafts. The author reveals criteria, indicators and levels of training specialists, stages of implementating the system of reasoned pedagogical conditions into a teaching and educational process of a university in regard to training maintenance personnel teachers to use artistic handicrafts in a teaching and educational process.

Key words: educational potential of artistic handicrafts; educational functions of artistic handicrafts; searching and creative, potentially possible, satisfactory, poor levels of training maintenance personnel teachers to use artistic handicrafts in a teaching and educational process.

У сучасному суспільстві посилюється акцент на виявлення місця i ролі культуротворчої діяльності людини та іiі реалізації в усіх галузях життя. У багатовимірному культурному просторі особливе місце посідає розвиток декоративно-прикладного мистецтва та вивчення його освітньо-виховного потенціалу. Народне мистецтво, й зокрема художні ремесла, що зберігають історичну пам'ять, $\epsilon$ безпосереднім носієм самобутньої культури, мистецтва минулих поколінь, відображають педагогічний досвід народу, є важливим засобом виховання гармонійно розвиненої особистості, розвитку іiі моральної, трудової, естетичної, технологічної культури і розглядається як важливий компонент професійно-педагогічної підготовки майбутніх учителів обслуговуючої праці.

Теоретичний аналіз спектру питань зазначеної проблеми, науково-методичного забезпечення та практичного стану їі розв'язання 3 позиції використання художніх ремесел учителями обслуговуючої праці свідчить про наявність суперечностей між:

- культурно-історичним потенціалом художніх ремесел та його недостатньою реалізацією у змісті професійної підготовки вчителів обслуговуючої праці;

- потребою сучасної системи освіти в учителях, які володіють основами художніх ремесел, та відсутністю цілісної системи вивчення художніх ремесел у професійній підготовці вчителя обслуговуючої праці;

- постійним розвитком нових педагогічних i виробничих технологій 3 оволодіння художніми ремеслами та відродженням і збереженням історичного, соціального, культурного досвіду художніх ремесел у трудовій діяльності народу.

Отже, проблема підготовки вчителів обслуговуючої праці до використання художніх ремесел у навчально-виховному процесі постає актуальною для іiі теоретичного та практичного розв'язання.

Важливо відзначити, що вивчення філософської, психолого-педагогічної та спеціальної літератури свідчить про інтерес науковців до вивчення різних аспектів проблеми використання художніх ремесел у навчально-виховному процесі: теоретичні і методичні позиції декоративно-прикладного мистецтва (П. Богатирьов, Г. Васьківська, Т. Дем'янюк, П. Дробов’язко, В. Жигірь, М. Кузан, Т. Мацейків, В. Мусієнко, С. Нікітчина, Л. Оршанський, С. Павх); освітньо-виховна та психологопедагогічна сутність складників народного мистецтва (І. Зязюн, І. Крип'якевич, Ю. Руденко); еволюція народного мистецтва та закономірності розвитку (Є. Антонович, Р. Захарчук-Чугай, А. Іванченко, Т. Ніколаєва, Б. Прокопович); 
залучення студентів до народних ремесел та навчання технікам їх виконання (В. Барадулін, Т. Кари-Васильєва, В. Качнєєва, В. Радкевич).

Водночас мало дослідженою залишається проблема підготовки майбутніх учителів, які могли б максимально ефективно реалізувати освітньо-виховні функції декоративно-прикладного мистецтва.

Mema cmammi- обгрунтувати систему педагогічних умов підготовки вчителів обслуговуючої праці до використання художніх ремесел у навчально-виховному процесі.

Дослідження теоретико-методологічних засад підготовки вчителів обслуговуючої праці до використання художніх ремесел у системі трудової освіти спонукало нас до вивчення філософської, психолого-педагогічної та спеціальної літератури 3 позиції розкриття змісту, особливостей підготовки вчителів обслуговуючої праці, виявлення сутнісних характеристик художнього ремесла та його освітньо-виховних можливостей, дослідження історико-педагогічної ретроспективи системи навчання художнім ремеслам та обгрунтування педагогічних умов підготовки вчителя обслуговуючої праці до використання художніх ремесел у навчальновиховному процесі.

Саме такий підхід до вивчення проблеми спонукає нас до осмислення сутності художніх ремесел в освітньо-виховному аспекті у такій логіці «культура національна культура - народне мистецтво - художні ремесла - освіта» через закони взаємозв'язку загального й окремого, цілісності як системи динамічної взаємодії визначених компонентів.

На підставі аналізу наукової літератури ми можемо говорити про інтерес дослідників до вивчення різних аспектів проблеми використання художніх ремесел у навчально-виховному процесі: теоретичні і методичні позиції декоративноприкладного мистецтва (П. Богатирьов, Г. Васьківська, Т. Дем'янюк, П. Дробов'язко, В. Мусієнко); освітньо-виховна та психолого-педагогічна сутність складників народного мистецтва (І. Зязюн, І. Крип'якевич, Ю. Руденко); еволюція народного мистецтва та закономірності розвитку (С. Антонович, Р. Захарчук-Чугай); залучення студентів до народних ремесел та навчання технік їх виконання (В. Барадулін, I. Каньковський, Т. Кари-Васильєва, В. Радкевич). Їх глибоке вивчення дозволяє нам виокремити такі основні функції художніх ремесел: соціально-ціннісна, етнічносоціальна, традиційно-історична, статусно-позиційна, утилітарно-практична, художньо-естетична, професійно-ціннісна.

Професійний інтерес учителя обслуговуючої праці- трудова підготовка студентів; безперечна популярність визначених видів народних ремесел в усі часи; абсолютна погодженість у теоретичному визначенні названих видів як художніх ремесел та їх оцінці; інтегративний та комплексний характер визначених видів у зв'язку між собою та 3 іншими видами національного мистецтва; висока функціональність визначених видів художніх ремесел, у тому числі в освітньовиховному аспекті та найменша дослідженість їх саме в цьому аспекті спрямовує наші наукові інтереси на такі ремесла, як вишивка, ткацтво, виготовлення національного одягу.

Історична ретроспектива освітньо-виховної практики оволодіння художніми ремеслами дозволяє зробити висновки: по-перше, про те, що розвиток художнього ремесла зумовлено соціальним запитом; по-друге, шляхи оволодіння художнім ремеслом динамічно змінювалися відповідно до змін в освітньо-виховній системі; потретє, в оволодінні художнім ремеслом тією чи тією мірою превалювали художньоутилітарна практика, творчогенні психологічні важелі, освітньо-виховні технології, 
відповідні до часу та навчально-виховної системи; по-четверте, розвиток загальноосвітнього характеру оволодіння художніми ремеслами посилює тенденцію педагогізації означеного процесу. Значною мірою ефективність процесу залежить від компетентності вчителя; по-п'яте, динамічні зміни в освітньо-виховній практиці 3 оволодіння досліджуваними художніми ремеслами створили соціально-педагогічні передумови підготовки вчителя-фахівця обслуговуючої праці.

Глибоке розуміння цього та висновки, зроблені на основі аналізу спеціальних досліджень науковців щодо підготовки вчителя (Н. Андреєва, О. Кобернік, Б. Прокопович, В. Пікельна, В. Сидоренко, Д. Тхоржевський), сприяли осмисленню підготовки вчителів обслуговуючої праці до використання художніх ремесел у навчально-виховному процесі визначається як складне особистісне утворення, $\epsilon$ інтегральним показником професійної підготовки вчителя і містить у собі різного роду установки на усвідомлення певної педагогічної проблеми, моделі ймовірної поведінки, визначення спеціальних способів творчої взаємодії з учнями та оцінку своїх можливостей у досягненні позитивних результатів навчально-виховної діяльності.

Практично всі дослідники одностайні в думці, що функції вчителя трудового навчання не обмежуються наданням професійних знань і формуванням трудових умінь і навичок, організацією навчально-виховного процесу. Він забезпечує розвиток особистості майбутнього трудівника, готує вихованців до вирішення конкретних задач. За визначенням О. Коберніка, такий учитель «має бути мобільним, готовим до стрімкових змін у змісті технологічної підготовки, здатним швидко переорієнтуватися» [6, с. 30]. Своє бачення 3 підготовки вчителя визначає В. Кузь: «учитель має бути не тільки предметником чи навіть викладачем двох предметів, а й володіти народними ремеслами, знатися на техніці, бути взірцем у побуті, одязі, етикеті, загалом бути творчою особистістю» [7, с. 19].

Дослідження надало нам змогу довести, що продуктивна підготовка вчителів обслуговуючої праці до використання художніх ремесел у професійній діяльності відбуватиметься за таких педагогічних умов: осмисленість студентами потреби у відродженні та розвитку досліджуваних художніх ремесел із позиції суспільноцільового, професійно-діяльнісного та професійно-особистісного підходів; формування високого рівня мотивації до професійної діяльності, психологічний комфорт, професійна самореалізація засобами досліджуваних художніх ремесел; орієнтація логіки та змісту теоретичної і практичної підготовки майбутніх фахівців на виокремлення національно-культурного складника художніх ремесел у психологічному, педагогічному та мистецтвознавчому контексті; цілеспрямовану діяльність педагогічного колективу ВНЗ із залучення студентів до реалізації творчих мистецтвознавчих, психолого-педагогічних знань, умінь і навичок через усі види й форми навчальної та виховної роботи.

Упровадження системи педагогічних умов підготовки вчителів обслуговуючої праці до використання художніх ремесел у навчально-виховному процесі ми поклали в основу дослідно-експериментальної роботи щодо підготовки вчителів обслуговуючої праці до використання художніх ремесел у навчально-виховному процесі.

Задля цього схарактеризовано критерії (мистецтвознавча обізнаність, психологічна настанова та методична обізнаність майбутніх учителів обслуговуючої праці до відповідної діяльності), показники, рівні (пошуково-творчий, потенційноможливий, задовільний, недостатній) підготовки майбутніх учителів обслуговуючої праці до використання художніх ремесел у власній професійній діяльності. 
Мистецтвознавчу обізнаність у галузі досліджуваних художніх ремесел визначено такими показниками: розуміння освітньо-виховних можливостей художніх ремесел; технологічна обізнаність із процесом виконання художніх творів; індивідуальний стиль виконання художніх творів.

Показниками психологічної настанови на розв'язання творчих, освітніх i виховних завдань засобами художніх ремесел (ткацтво, вишивка і виготовлення національного одягу) вважали: інтерес до теоретичного і практичного оволодіння досліджуваними художніми ремеслами; мотив самореалізації студента в оволодінні художніми ремеслами.

До показників методичної обізнаності вчителів обслуговуючої праці до професійного використання художніх ремесел віднесено: вміння визначити дидактичну, виховну і розвивальну цінність художніх ремесел та їх реалізацію у співробітництві 3 учнівським колективом; оволодіння методикою викладання художніх ремесел: ткацтва, вишивки, виготовлення національного одягу на уроках обслуговуючої праці; здатність організувати залучення учнів до художніх ремесел у позакласній роботі (гуртки, клуби, вікторини, конкурси, експедиції); морально-етичне сприйняття художньо-творчих виробів; розвиток учнівського інтересу до мистецтвознавчої діяльності.

Започатковуючи експериментальну роботу, важливо проаналізувати навчальні плани та робочі програми, що дозволяє виявити, що навчальні програми дисциплін практично всіх циклів, окрім професійної підготовки, мають загальноосвітню предметно-визначену спрямованість і практично нічим не різняться від програм цих дисциплін, коли за ними навчаються студенти інших спеціальностей. Невиправдано поза увагою залишається фахова орієнтація програм. Дослідження робочих програм, безпосередньо орієнтованих на вивчення художніх ремесел, які є базисними в нашому дослідженні, дозволяють зробити такі висновки: практично всі програми в незначному обсязі, але обов'язково містять елементи змісту щодо художніх ремесел: ткацтва, вишивки i; у зовсім незначному обсязі - виготовлення національного одягу; кожна програма розрахована на одержання теоретичних знань та набуття практичних умінь; між програмами існує певний зв'язок, зумовлений предметною спрямованістю дисциплін.

У ході констатувального експерименту за допомогою анкетування, бесіди, спостереження за роботою в майстернях, оцінки виконання самостійних завдань, конкурсу на кращу творчу роботу, творчих завдань, інтерв'ю, аналізу результатів діяльності студентів установлено реальний стан підготовки вчителів обслуговуючої праці до використання художніх ремесел у професійній діяльності; особливості використання художніх ремесел учителями різних освітньо-кваліфікаційних рівнів; взаємозумовленість складників підготовки вчителів обслуговуючої праці до використання художніх ремесел, реалізації їх освітньо-виховних можливостей у навчально-виховному процесі; чинники різнорівневої підготовки вчителів обслуговуючої праці.

Грунтовний аналіз результатів констатувального експерименту свідчить про наявність великої кількості студентів, яким притаманний недостатній рівень підготовки до використання художніх ремесел у навчально-виховному процесі. В експериментальній групі такий показник сягає $65 \%$ респондентів, а в контрольній $70 \%$ учителів обслуговуючої праці. Задовільний рівень підготовки демонструють 30 \% студентів експериментальної та контрольної груп. Потенційно-можливий рівень зафіксовано лише в $5 \%$ респондентів експериментальної групи. Студентів із пошуково-творчим рівнем підготовки не виявлено взагалі. 
Формувальний експеримент мав за мету створення навчально-виховного середовища, яке забезпечувало б результативність реалізації в навчально-виховному процесі вищої школи розробленої моделі впровадження системи педагогічних умов підготовки вчителів обслуговуючої праці до використання художніх ремесел.

На першому (підготовчому) етапі формувального експерименту шляхом використання профорієнтації; створення можливостей здійснення соціально значущої, професійно-визначеної та особистісно значущої діяльності з використання художніх ремесел у різних соціальних середовищах (навчання в колективі, сім’ї, школі, творчому колективі) реалізації підлягає педагогічна умова - осмисленість студентами потреби у відродженні та розвитку досліджуваних художніх ремесел із позиції суспільно-цільового, професійно-діяльнісного та професійно-особистісного підходів.

Педагогічна умова- формування високого рівня мотивації до професійної діяльності, психологічний комфорт професійної самореалізації засобами досліджуваних художніх ремесел- має бути реалізована на другому (пізнавальному) етапі формувального експерименту за допомогою діагностування індивідуального інтересу до досліджуваних художніх ремесел, урахування інтересу в усіх видах навчальної діяльності: теоретичні і практичні заняття, самостійна робота студентів; забезпечення психологічного комфорту навчально-виховного процесу через суб'єктивну систему відносин.

На третьому (діяльнісному) етапі формувального експерименту доречно здійснювати реалізацію педагогічної умови - орієнтація логіки та змісту теоретичної та практичної підготовки майбутніх фахівців на виокремлення національнокультурного складника художніх ремесел у психологічному, педагогічному та мистецтвознавчому контексті. Засоби реалізації цієї умови - вдосконалення змісту підготовки в логіці: технологічні вміння й навички $\rightarrow$ теоретичне та практичне осмислення освітньо-виховних можливостей художніх ремесел та засобів їх реалізації у професійній діяльності $\rightarrow$ творчий рівень професійної самореалізації; художньомистецька діяльність у період технологічної практики; системність використання освітньо-виховних можливостей художніх ремесел у період педагогічних практик; інтерактивність змісту навчальних предметів, змісту самостійної роботи студентів, науково-дослідної роботи студентів, виховної роботи.

Реалізація педагогічної умови - цілеспрямована діяльність педагогічного колективу із залучення студентів до реалізації творчих мистецтвознавчих, педагогічних знань, умінь та навичок через усі види та форми навчально-виховної діяльності- здійснюється на четвертому (творчому) етапі формувального експерименту шляхом використання особистісно зорієнтованої технології навчання; рефлексивного характеру пізнавальної діяльності через інтегративні методи та нестандартні форми навчання; співробітництва суб'єктів педагогічного процесу (цеховий осередок).

Ефективність реалізації системи педагогічних умов підготовки вчителів обслуговуючої праці до використання художніх ремесел у професійній діяльності перевіряється на контрольному етапі експериментальної роботи. Динаміку рівнів підготовки майбутніх учителів обслуговуючої праці до використання художніх ремесел у навчально-виховному процесі подано в табл. 1. 
Динаміка рівнів підготовки майбутніх учителів обслуговуючої праці до використання художніх ремесел у навчально-виховному процесі ( \%)

\begin{tabular}{|c|c|c|c|c|}
\hline \multirow{2}{*}{ Рівні } & \multicolumn{2}{|c|}{ Контрольна група } & \multicolumn{2}{|c|}{ Експериментальна група } \\
\cline { 2 - 5 } & $\begin{array}{c}\text { Констатувальний } \\
\text { експеримент }\end{array}$ & $\begin{array}{c}\text { Контрольний } \\
\text { експеримент }\end{array}$ & $\begin{array}{c}\text { Констатувальний } \\
\text { експеримет }\end{array}$ & $\begin{array}{c}\text { Контрольний } \\
\text { експеримент }\end{array}$ \\
\hline $\begin{array}{c}\text { Пошуково- } \\
\text { творчий }\end{array}$ & 0 & 5 & 0 & 25 \\
\hline $\begin{array}{c}\text { Потенційно- } \\
\text { можливий }\end{array}$ & 0 & 5 & 5 & 35 \\
\hline Задовільний & 30 & 30 & 30 & 35 \\
\hline Недостатній & 70 & 60 & 65 & 5 \\
\hline
\end{tabular}

Отримані дані відображають позитивну динаміку зростання рівня підготовки майбутніх учителів до використання художніх ремесел у навчально-виховному процесі. Суттєві позитивні зміни відбулися в експериментальній групі. Так, пошуково-творчий рівень виявлено під час контрольного експерименту у $25 \%$ учителів обслуговуючої праці, тоді як під час констатувального експерименту респондентів з означеним рівнем не зафіксовано. Кількість студентів із потенційноможливим рівнем зросла $35 \%$ під час констатувального експерименту до $35 \%$ - під час контрольного експерименту. Дещо зросла кількість респондентів, які перебували на задовільному рівні: $330 \%$ при констатувальному обстеженні до $35 \%$ на етапі контрольного експерименту. Суттєво знизилась кількість студентів, у яких виявлено низький рівень означеної підготовки: 365 \% під час констатувального експерименту до 5 \% під час контрольного експерименту.

Аналіз результатів дозволяє стверджувати, що процес підготовки вчителів обслуговуючої праці до використання художніх ремесел у навчально-виховному процесі за дотримання системи педагогічних умов більш успішний, ніж традиційне навчання, та засвідчує зростання рівнів підготовки майбутніх учителів за кожним критерієм. Застосування в навчально-виховному процесі вищої школи проблемних ситуацій, завдань, дискусій сприяло самореалізації студентської молоді.

У контрольній групі відбулися незначні позитивні зміни. До пошуково-творчого та потенційно-можливого рівнів на контрольному етапі піднялося до $5 \%$ респондентів, на констатувальному етапі означених рівнів не зафіксовано взагалі. Кількість студентів на середньому рівні залишилася незмінною (30\%). Дещо зменшилася кількість респондентів, які перебували на низькому рівні підготовки (з 70 \% під час констатувального обстеження до 60 \% під час контрольного обстеження).

Проведене дослідження виявило залежність між установкою на педагогічну працю, позитивним ставленням до професії вчителя та відродженням художніх ремесел, характером і рівнем фахової підготовки студентів. На підставі аналізу результатів реалізації у навчально-виховному процесі вищої школи системи педагогічних умов підготовки вчителів обслуговуючої праці до використання художніх ремесел установлено, що орієнтація фахової підготовки на особистість студента, різноманітність іiі форм та методів забезпечує пошуково-творчий та потенційно-можливий рівень підготовки фахівців.

\section{Література}

1. Васьківська Г. О. Національна культура в системі громадянської освіти / Г. О. Васьківська // Відродження. - 1997. - № 3. - С. 12-15. 2. Дем'янюк Т. Д. Зміст та методика народознавчої роботи в сучасній школі / Т. Д. Дем'янюк. - К. : ІСДО, 
1996. - 108 с. 3. Дробов'язко П. І. Українська національна школа: витоки і сучасність / П. І. Дробов'язко. - К. : Академія, 1997. - 184 с. 4. Жигірь В. І. Зміст фахової підготовки вчителя обслуговуючої праці у вищому навчальному закладі: дис. ... канд. пед. наук : 13.00.01 / Вікторія Іванівна Жигірь; Бердянський держ. пед. ін-т ім. П. Д. Осипенко. - Бердянськ, 2001. - 207 с. 5. Знамеровська Н. П. Підготовка вчителя трудового навчання до розвитку художньо-конструкторських здібностей учнів основної школи : дис. ... канд. пед. наук : 13.00.02 / Наталія Павлівна Знамеровська ; Херсонський держ. пед. ун-т. - Херсон, 1999. - 231 с. б. Кобернік О. Модернізація підготовки майбутніх учителів / Олександр Кобернік// Трудова підготовка в закладах освіти. - 2004. - № 4. - С. 28-30. 7. Кузь В. Г. Учитель, школа пріоритети XXI ст. / В. Г. Кузь // Педагогіка і психологія. - 2002. - № 1-2. - С. 11-19.

УДК 377.031

Ірина Казанжи

\section{СУЧАСНІ ПІДХОДИ ДО ПРОФЕСІЙНОЇ ПІДГОТОВКИ ВЧИТЕЛЯ ПОЧАТКОВОЇ ШКОЛИ}

Казанжи І. В. Сучасні підходи до професійної підготовки вчителя початкової школи.

У статті проаналізовано сучасні підходи до професійної підготовки майбутніх учителів початкових класів, визначено умови модернізації підготовки вчителя початкової школи в системі вищої педагогічної освіти.

Ключові слова: професійна підготовка, інноваційна діяльність, фундаменталізація освіти, модернізація вищої педагогічної школи, персоналізований підхід.

Казанжи И. В. Современные подходы к профессиональной подготовке учителя начальной школы.

В статье проанализированы современные подходы к профессиональной подготовке будущих учителей начальних классов, определены условия модернизации подготовки учителя начальной школы в системе высшего педагогического образования.

Ключевые слова: профессиональная подготовка, инновационная деятельность, фундаментализация образования, модернизация высшей педагогической школы, персонализированный подход.

Kazanzhi I. V. Modern approaches to professional training future primary school teachers.

The article analyzes modern approaches to professional training future primary school teachers and defines conditions concerning the issue how to modernize training primary school teachers in the higher pedagogical education system.

Key words: professional training, innovative activity, fundamentalization of education, modernization of higher pedagogical school, personalized approach.

На сучасному етапі розвитку української держави помітно зросла увага до наукових досліджень, спрямованих на вдосконалення професійної підготовки майбутнього вчителя. Сучасна педагогічна наука спрямована на реформування системи освіти в Україні. Зміна життєдіяльності суспільства й розширення міжнародних зв'язків потребує від сучасної освіти підвищення рівня майбутніх 